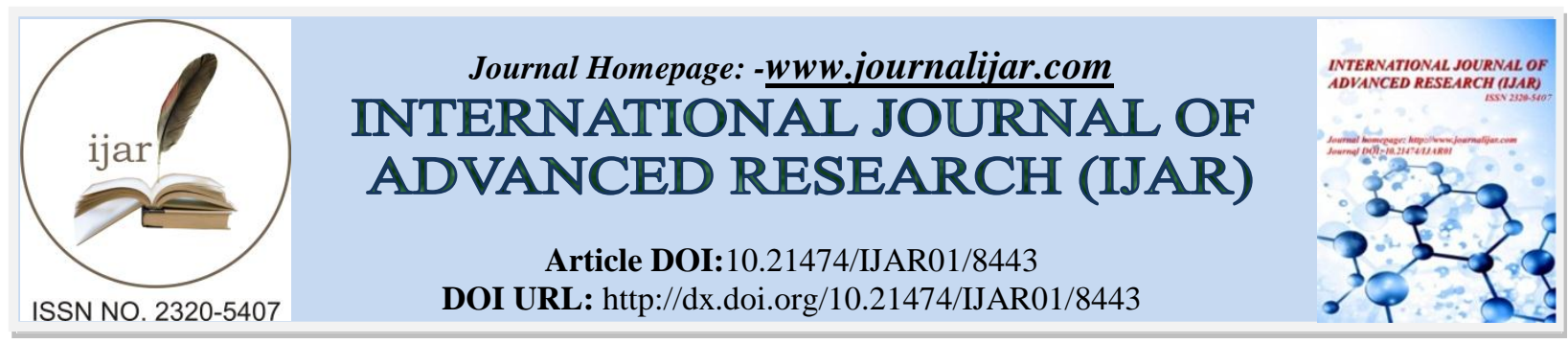

RESEARCH ARTICLE

\title{
THE DEVELOPMENT OF INTEGRATED SCIENCE MODULE FOR STUDENTS CLASS VII MATERIALS OF EARTH AND DYNAMICS STRUCTURE.
}

\author{
Sri Susayang. \\ Graduate Student of Science Education University of Jember, Teacher in SMP 5 Situbondo.
}

\section{Manuscript Info}

Manuscript History

Received: 20 November 2018

Final Accepted: 22 December 2018

Published: January 2019

Key words:-

Integrated Science Module,

Science learning,

Earth structure and dynamics.

\begin{abstract}
Integrated ScienceModuleis used to help students learn independently and train students to determine their own learning. This study aims to develop teaching materials in the form of Integrated ScienceModule in scientific approaches and know the effectiveness of the module that is known based on learning outcomes and student responses. This study is used Research and Development method with Four-D model that is defined, design, developand disseminate. According to the validation result, the moduledeclared eligible to be usedin learning with small revision. The product test was conducted on 26 students of SMP Negeri 5 Situbondo Class VII F. The result of the experiment obtained N-gain data of cognitive learning outcomes ( $\mathrm{N}$ - gain of Pre test-Post test) of 0.74 which isa highcategory, it shows an increase of learning outcomes after using the module. Assessment of learning outcomes shows $92 \%$ of students achievedcompleteness and student responses to the presentation showed the good response of $88 \%$. Based on the results of the experiment it can be concluded that the module is feasible and effective for use in junior high school.
\end{abstract}

Copy Right, IJAR, 2017,. All rights reserved.

\section{Introduction:-}

Science subjects in junior high school education level are presented in an integrated field consisting of physics, chemistry, biology and earth science and space. By learning, science students can understand natural phenomena and phenomena, and use their knowledge to solve problems in everyday life. The concept of integrating science subjects begins with biological phenomena around students and discusses them with reviews from three other fields of study (Zubaida el al., 2015:4). Through integrated science learning, students are expected to actively find their own knowledge according to the information they get from their environment. Meaningful Learning is needed so that students can learn science well.

Dahar states (2006: 95), meaningful learning according to Ausubel learning theory is the process of associating new information with a person's cognitive structure. In accordance with the theory, the 2013 curriculum mandates that the implementation of science lessons in junior high school through a scientific approach. A scientific approach is a learning approach that invites students to conduct knowledge-seeking processes related to the subject matter through various scientific activities, students are directed to discover the facts themselves, construct new concepts and values necessary for life (Putra, 2013: 12). Implementation of a scientific approach in science learning requires teachers who can guide students to discover their own knowledge, build new concepts based on the information they get.

Corresponding Author:-Sri Susayang.

Address:-Graduate Student of Science Education University of Jember, Teacher in SMP 5 Situbondo. 
That is why teachers need good logical thinking in order to sort the subject matter, formulate it briefly and densely and transmit it into logical order structure and easily understood (Suciati, 2005: 14). To realize it is needed tool aids in the form of teaching materials

One of the teaching materials that can be used is a module. Integrated science modules are used to help students learn independently and train students to determine their own learning. According to Mulyasa (2003: 149), module learning has a goal to improve the efficiency and effectiveness of learning in schools, in order to achieve optimal learning objectives. Pratiwi (2014) in his research stated that module development can improve the ability of critical thinking and student learning outcomes.

Based on the observation of science subjects teachers in Situbondo Regency is known that students still do not use the teaching materials in the form of modules. This is due to not yet available learning module Science and teachers have not been able to develop the module due to time constraints, limited funds and most teachers do not understand module development procedures. An alternative solution to solve the problem is to develop teaching materials in the form of an integrated science-based learning module based on a scientific approach.

The material chosen by the researcher is the material of earth structure and its dynamics, because this material is new material that must be presented in science lesson in junior high school based on the regulation of the minister of education and culture No. 24 the year 2016, so it is necessary the teaching materials that can help in presenting the material of earth structure and dynamics. Research on the development of integrated science module has been done by several researchers, among others: Sugiyanto (2013), Sujiono (2014), Astuti (2016), but there is no research on the development of integrated science module on the earth structure material and dynamics, it is necessary to conductresearch on development of integrated science module for students of first grade on earth structure material and itsdynamics. This study aims to develop teaching materials in the form of integrated science modules in sciencebased learning approaches and know the effectiveness of modules that are known based on learning outcomes and student responses.

\section{Research Methods:-}

This research uses Research and Development method with Four-D model that is defined, design, develop and disseminate. According to the development model by Thiagarajan (1974), the first stage is defined. At the stage of the definition of several steps include: 1) the from - end analysis, is done to establish the basic problems faced in science learning so that the required development of teaching materials in the form of modules. 2) Learner analysis is done to examine the characteristics of students for learning modules developed according to the needs of students, 3) Concept analysis is done to examine the characteristics of the material, task analysis performed to determine the contents of the material to fit the competencies to be achieved, 4) specifying objectives to adjust the results concept analysis with learning objectives to be achieved.

The second stage is the design, this stage is designing modules and research instruments so that the draft module generated. The third stage is the development, at this stage module validation by user or teacher experts and revision of the module to get the draft module ready for use for testing. After the trial, the module was revised again until it was found that the appropriate module used for junior high school in firstgrade. The fourth stage is dissemination. The module product dissemination stage is carried out by the developer by distributing the development result module to the science teacher for use in the lesson.

Module validation by education experts includes module assessments by material experts, development experts, and media experts. Validation by the user is a senior teacher from 3 schools, with criteria for more than 10 years working life, minimum education S1 IPA (Science or Biology study program) and Science teachers. The experiments were conducted in the learning by using integrated science module which has been designed for 26 respondents of first grade in SMP Negeri 5 Situbondo with almost the same academic ability. The trial process is done through direct learning activities in accordance with the stated in the RPP (lesson plan) that is as much as 3 timesmeeting with an allocation of time of 80 minutes per meeting. Trial results will be obtained quantitative data in the form of assessment scores from the validator, the value of pretest-posttest, and qualitative data in the form of suggestions and comments from teachers and students as module users. Data collection instruments used were product validation questionnaires, student response questionnaires and assessment sheets (pretest-post issues). 
After validation and then validation results are analyzed and obtained an average score. The average score obtained based on the results for scores obtained with a maximum score multiplied by 100 (Akbar, 2013: 82). Scores are expressed with invalid criteria if the score is 25 to 43,75 , meaning the module cannot be used. The criterion is less valid if the score is 43.75 to 62.75 , meaning the module may be used with large revisions. The criteria are quite valid if the score is 62.75 to 81.25 , meaning that the modulemay be used with small revisions. The criteria are valid the score is 81.25 to 100 , meaning the module may be used without revision.

Questionnaire result data to know student response to the module is analyzed by counting using the formula below $\mathrm{PR}=$ (number of scores obtained) / (total score maximum) $\mathrm{x} 100 \%$

The percentage of the result of the response of the learners' learners obtained is then converted into qualitative data using criteria in table 1.

Table 1:-Module eligibility criteria

\begin{tabular}{|c|c|}
\hline Persentase $(\%)$ & Category \\
\hline $81,25<\mathrm{x}<100$ & Very effective \\
\hline $62,5<\mathrm{x}<81,25$ & effevtive \\
\hline $43,75<\mathrm{x}<62,5$ & Effective enough \\
\hline $25<\mathrm{x}<43,75$ & Not effective \\
\hline
\end{tabular}

(Modified in Akbar, 2013: 82)

Integrated science modules can be used in learning if they fall into effective or highly effective categories.

To find out whether the product of the development of an effective module for use in learning in junior high school is also assessed by analysis of learning outcomes through tests in the form of data improvement test results learners learn. Increased test results of these learners in the analysis using the formula of N-gain as follows:

$$
\text { N-gain } \frac{\text { Spost - Spre }}{=} \times 100 \%
$$

(Hake, 1998)

\section{Information:-}

$\mathrm{N}$-gain $=$ normalized gain

Spost $=$ post-test score

Spre $=$ pre-test score

Smax $=$ maximum score

Tabel 2:-Criteria for N-gain score

\begin{tabular}{|c|c|}
\hline Restrictions & Category \\
\hline $\mathrm{N}$-gain $\geq 0,7$ & High \\
\hline $0,3 \leq \mathrm{N}$-gain $<0,7$ & Medium \\
\hline $\mathrm{N}$-gain $<0,3$ & Low \\
\hline
\end{tabular}

(Hake, 1998)

If the results of data analysis of learning outcomes in the high category then integrated science module developed effective assessed for use for learning in junior high school.

\section{Result And Discussion:-}

The development result is an integrated science module consisting of a module for students and instructions for using the module for teachers. The teacher module usage module developed includes cover page; foreword; table of contents; background: explanation of module; module development goals; module usage procedures; RPP; evaluation. The module component for students consists of: cover page; foreword; table of contents; preliminary; learning objectives; concept maps; material description; exercise; summary; evaluation sheets; follow-up; key evaluation answer. 
The validation process of integrated science learning module is done more than once and then revised repeatedly until the value obtained on each component of the module compiler shows valid or valid criteria so it is feasible to use. The validation performed by development experts and media experts is done twice each until the valid criteria are obtained for each component of the integrated science module. Validation by material experts is done twice until the concept of material in the integrated science module is said to be valid.

Data obtained from this research is data of product validation result in the form of module and data of trial result. Data obtained validation results are divided into two kinds, namely quantitative data and qualitative data. Expert validation results can be seen in the table below.

Table 3:-Data Summary of component validation result of content feasibility

\begin{tabular}{|c|c|c|c|}
\hline \multirow[t]{2}{*}{ Rated aspect } & \multicolumn{2}{|c|}{ Score } & \multirow[t]{2}{*}{ everage } \\
\hline & $\begin{array}{l}\text { Expert Valida } \\
\text { tion }\end{array}$ & $\begin{array}{l}\text { User Valida } \\
\text { tion }\end{array}$ & \\
\hline 1. Clarity of learning objectives & 3,5 & 3,33 & \\
\hline $\begin{array}{l}\text { 2. The breadth of the material according to the } \\
\text { learning objectives }\end{array}$ & 3 & 3,33 & \\
\hline $\begin{array}{l}\text { 3. Depth of material in accordance with the } \\
\text { purpose of learning }\end{array}$ & 3 & 3,33 & \\
\hline 4. Accuracy of facts and data & 3 & 3 & \\
\hline 5. Legal / concept / theory accuracy & 3 & 3 & \\
\hline 6. Accuracy of instances and cases & 3 & 3 & \\
\hline 7. Accuracy of images, diagrams, illustrations & 3 & 3 & \\
\hline 8. Compatibility with integrated IPA materials & 3,5 & 3 & \\
\hline $\begin{array}{l}\text { 9. Present concrete examples from the local / } \\
\text { national / regional / international environment }\end{array}$ & 2,5 & 2,67 & \\
\hline amount & 27,5 & 27,67 & 27,58 \\
\hline Validation Score & 83,68 & 88,31 & 86,20 \\
\hline Criteria & valid & valid & valid \\
\hline
\end{tabular}

Table 4:-Summary of Results Data Validation of components of presentation feasibility

\begin{tabular}{|l|c|c|c|}
\hline \multicolumn{1}{|c|}{ Rated aspect } & \multicolumn{2}{|c|}{ Score } & \multirow{2}{*}{ average } \\
\cline { 2 - 3 } & $\begin{array}{l}\text { Expert Valida } \\
\text { tion }\end{array}$ & $\begin{array}{l}\text { User Valida } \\
\text { tion }\end{array}$ & \\
\hline $\begin{array}{l}\text { 1. The consistency of systematic serving in learning } \\
\text { activities }\end{array}$ & 3,33 & 3,67 & \\
\hline 2. Jogging presentation and conceptual demands & 3,33 & 3,00 & \\
\hline $\begin{array}{l}\text { 3. The suitability and accuracy of illustrations and } \\
\text { materials }\end{array}$ & 3,33 & 3,00 & \\
\hline $\begin{array}{l}\text { 4. Generating motivation to learn at the beginning } \\
\text { of the chapter }\end{array}$ & 3,67 & 3,00 & \\
\hline $\begin{array}{l}\text { 5. The accuracy of writing and selection of } \\
\text { references/reference sources for text, tables and } \\
\text { drawings }\end{array}$ & 3,00 & 3,33 & \\
\hline $\begin{array}{l}\text { 6. The precision of numbering and naming } \\
\text { tables/drawings }\end{array}$ & 3,33 & 3,33 & \\
\hline $\begin{array}{l}\text { 7. Active involvement of learners and focused on } \\
\text { the students }\end{array}$ & 3,33 & 3,33 & \\
\hline 8. Using a scientific approach & 3,00 & 3,67 & \\
\hline $\begin{array}{l}\text { 9. Create interactive communication and generate } \\
\text { feedback for self-evaluation }\end{array}$ & 3,00 & 3,00 & \\
\hline 10. Integration in learning & 3,33 & 3,67 & \\
\hline 11. Completeness of the introductory component & 3,33 & 3,67 & \\
\hline 12. Clarity of instructions for module usage & 3,67 & 3,33 & \\
\hline 13. Clarity of summary & 3,67 & 3,33 & \\
\hline
\end{tabular}




\begin{tabular}{|c|c|c|c|}
\hline 13. The accuracy of understanding on the glossary & 3,33 & 3,33 & \\
\hline 15. Updates of bibliography & 3,33 & 3,00 & \\
\hline $\begin{array}{l}\text { 16. The accuracy of evaluation appropriate to the } \\
\text { learning objectives }\end{array}$ & 3,33 & 3,00 & \\
\hline Amount & 53,33 & 53,6 & 53,50 \\
\hline Validation Score & 83,33 & 83,8 & 83,59 \\
\hline Criteria & valid & valid & valid \\
\hline
\end{tabular}

Table 5:-Data Summary Validation results of language feasibility components

\begin{tabular}{|c|c|c|c|}
\hline \multirow{2}{*}{ Rated aspect } & \multicolumn{2}{|c|}{ Score } & \multirow{2}{*}{ Everage } \\
\hline & $\begin{array}{l}\text { Expert } \\
\text { Valida } \\
\text { tion }\end{array}$ & $\begin{array}{l}\text { User Valida } \\
\text { tion }\end{array}$ & \\
\hline 1. Compliance with the level of development of thinking learners & 3 & 3 & \\
\hline $\begin{array}{l}\text { 2. Conformity with the level of socio-emotional development of } \\
\text { learners }\end{array}$ & 3 & 3 & \\
\hline 3. Ability to motivate learners to respond to the role & 3 & 3 & \\
\hline 4. Ability to encourage learners to think critically & 4 & 3 & \\
\hline 5. The accuracy of sentence structure & 4 & 3,67 & \\
\hline 6. The kindness of the term & 3 & 3,67 & \\
\hline 7. Linkage between sub chapters / paragraphs / sentences & 4 & 3,67 & \\
\hline 8. Wholeness of meaning in sub chapter / paragraph / sentence & 3 & 3,33 & \\
\hline 9. Accuracy of grammar & 4 & 3,33 & \\
\hline 10. Accuracy of spelling & 4 & 3,33 & \\
\hline 11. Consistent use of the term & 4 & 4 & \\
\hline 12. The consistency of use of symbols or symbols & 4 & 3,67 & \\
\hline 13. The accuracy of writing scientific names & 4 & 4 & \\
\hline Amount & 47 & 44,67 & 45,83 \\
\hline Validation Score & 90,38 & 85,90 & 88,14 \\
\hline Criteria & valid & valid & valid \\
\hline
\end{tabular}

Table 6:-Data Summary The validation results of the feasibility component of the graft

\begin{tabular}{|l|c|c|c|}
\hline \multicolumn{1}{|c|}{ Rated aspect } & \multicolumn{2}{|c|}{ Score } & \multirow{2}{*}{ average } \\
\cline { 2 - 3 } & $\begin{array}{l}\text { Expert Valida } \\
\text { tion }\end{array}$ & $\begin{array}{l}\text { User Valida } \\
\text { tion }\end{array}$ & \\
\hline $\begin{array}{l}\text { 1. Conformity of book size with ISO A4 standard (210 } \\
\text { x 297 mm) or B5 (176 x 250 mm) }\end{array}$ & 4 & 3 & \\
\hline $\begin{array}{l}\text { 2. Display the layout of elements on the face of the } \\
\text { module (cover) harmonious and gives the impression } \\
\text { of a good rhythm }\end{array}$ & 3 & 3 & \\
\hline 3. Displaying a good point centre & 3 & 3 & \\
\hline $\begin{array}{l}\text { 4. The composition of layout elements (title, author, } \\
\text { illustration, etc.) is balanced and in tune with the } \\
\text { content location }\end{array}$ & 3 & 3 & \\
\hline 5. Size of proportional layout elements & & 3,33 & \\
\hline $\begin{array}{l}\text { 6. The colour of the layout harmonious and clarify the } \\
\text { function }\end{array}$ & 4 & 3 & \\
\hline 7. Show good contrast & 3 & 3 & \\
\hline 8. Proportional letter size & 3 & 3 & \\
\hline $\begin{array}{l}\text { 9. Illustrations can describe the contents/material of the } \\
\text { module }\end{array}$ & 3 & 3,67 & \\
\hline 10. The separation between paragraphs is clear & & 3 & \\
\hline
\end{tabular}




\begin{tabular}{|c|c|c|c|}
\hline $\begin{array}{l}\text { 11. The layout of both images and materials and } \\
\text { supporting features are consistent }\end{array}$ & 3 & 3,67 & \\
\hline $\begin{array}{l}\text { 12. The distance between the illustrations and the } \\
\text { corresponding text }\end{array}$ & 3 & 3 & \\
\hline 13. Conformity of shape, colour and size of the layout & 4 & 3,33 & \\
\hline $\begin{array}{l}\text { 14. Placement and appearance of chapter titles and } \\
\text { subtitles }\end{array}$ & 4 & 3,67 & \\
\hline 15. Placement and appearance of page numbers & 3 & 3 & \\
\hline $\begin{array}{l}\text { 16. Placement and appearance of illustrations and } \\
\text { drawings }\end{array}$ & 3 & 3 & \\
\hline 17. Placement of white space & 3 & 3 & \\
\hline $\begin{array}{l}\text { 18. Placement of titles, subtitles, illustrations and } \\
\text { captions does not interfere with understanding }\end{array}$ & 4 & 3,67 & \\
\hline 19. Interest and clarity of the letters used in the book & 4 & 3 & \\
\hline $\begin{array}{l}\text { 20. The use of variations of letters (bold, capital, italic, } \\
\text { all, small capital) is not excessive }\end{array}$ & 4 & 4 & \\
\hline 21. Overall illustrations correspond to the material & 3 & 3 & \\
\hline 22. Creative and dynamic & 3 & 3 & \\
\hline 23. Ease of use & 3 & 3,33 & \\
\hline 24. The ability of the media to increase knowledge & 4 & 3 & \\
\hline $\begin{array}{l}\text { 25. The ability of media to improve the motivation of } \\
\text { learners in learning the material }\end{array}$ & 4 & 3 & \\
\hline Amount & 85 & 81,67 & 83,33 \\
\hline Validation Score & 85,00 & 81,67 & 83,33 \\
\hline Criteria & valid & valid & valid \\
\hline
\end{tabular}

Table 7:-Data Summary Validation results of material feasibility components

\begin{tabular}{|l|c|c|c|}
\hline \multicolumn{1}{|c|}{ Rated aspect } & \multicolumn{2}{c|}{ Score } & \multirow{2}{*}{\begin{tabular}{l} 
average \\
\cline { 2 - 3 }
\end{tabular}} \\
\cline { 2 - 3 } & $\begin{array}{l}\text { Expert Valida } \\
\text { tion }\end{array}$ & $\begin{array}{l}\text { User } \\
\text { Valida } \\
\text { tion }\end{array}$ & \\
\hline 1. The concept used is an integrated IPA material & 4 & 3,33 & \\
\hline $\begin{array}{l}\text { 2. The concept is structured in a hierarchy, from a general } \\
\text { concept to a special concept }\end{array}$ & 4 & 3,67 & \\
\hline 3. Developing the learner's notifications & 3 & 3 & \\
\hline 4. Provide opportunities for learners to ask questions & 3 & 3 & \\
\hline 5. There are tasks/exercises to gather information & 3 & 4 & \\
\hline 6. Giving opportunities learners express ideas and thoughts & 3 & 3,67 & \\
\hline 7. Make a conclusion of the task & 3 & 3,67 & \\
\hline 8. Communicate the results of the task & 2 & 3 & \\
\hline $\begin{array}{l}\text { 9. Assessment instruments according to the learning } \\
\text { objectives }\end{array}$ & 2 & 3 & \\
\hline Amount & 27 & 30,33 & \\
\hline Validation Score & $\mathbf{7 5}$ & $\mathbf{8 4 , 2 6}$ & $\mathbf{2 9 , 6 7}$ \\
\hline Criteria & quite valid & valid & quite valid \\
\hline
\end{tabular}

Based on module validation results by experts and teachers, in general, the integrated science learning module on the earth structure material and its dynamics are included in the decent category with a validation score of 84.18 . This indicates that theproduct of development in the form of Integrated Science module based on the scientific approach of earth structure theme and its dynamics can be used in for science learning in junior high school. 
Although the whole component of integrated Science learning module is valid, it still needs to be improved on some components based on suggestions and comments from experts and also the assessment of module users. Comments and suggestions from validators are as follows:

Table 8:-Comments and Validator Suggestions for Feasibility of Content

\begin{tabular}{|l|l|}
\hline \multicolumn{1}{|c|}{ Rated aspect } & \multicolumn{1}{c|}{ Comments and Suggestions } \\
\hline 1. Basic Competence & $\begin{array}{l}\text { The presentation of basic competencies is presented in a } \\
\text { communicative language. }\end{array}$ \\
\hline 2. Material Accuracy & Images are clarified with easily readable drawings and source details \\
\hline 3. Material upgrades & $\begin{array}{l}\text { Need to reproduce concrete examples from the environment around } \\
\text { the student The order of the contents of what is fitting or not }\end{array}$ \\
\hline
\end{tabular}

Table 9:-Comments and Validator Suggestions for the feasibility of presentation

\begin{tabular}{|c|c|}
\hline Rated aspect & Comments and Suggestions \\
\hline 1. Presentation Technique & $\begin{array}{r}\text { Systematic serving in learning activities should be consistent } \bullet \text { Concepts } \\
\text { are presented in a coherent manner } \bullet \text { Preliminary components are } \\
\text { provided according to the BNSP module preparation manual }\end{array}$ \\
\hline 2. Supporting material presentation & $\begin{array}{l}\text { At the beginning of the chapter is expected presented material, pictures } \\
\text { or examples of cases that can generate student motivation to follow the } \\
\text { learning }\end{array}$ \\
\hline 3. Presentation of learning & $\begin{array}{l}\text { The sequence of steps to be undertaken in the learning activities, given } \\
\text { clear and coherent instructions so that students can use the module } \\
\text { independently }\end{array}$ \\
\hline 4. Completeness of presentation & $\begin{array}{r}\text { Each step of the module is given an explanation of the steps with } \\
\text { operational and coherent sentences } \\
\text { The accuracy of understanding on the glossary is tailored to the } \\
\text { understanding that the student understands }\end{array}$ \\
\hline
\end{tabular}

Table 10:-Comments and Validator Suggestions for language eligibility

\begin{tabular}{|l|l|}
\hline \multicolumn{1}{|c|}{ Rated aspect } & \multicolumn{1}{|c|}{ Comments and Suggestions } \\
\hline $\begin{array}{l}\text { 1. Conformity with the level of student } \\
\text { development }\end{array}$ & $\begin{array}{l}\text { Sentences are used to be simplified and clear so that students can more } \\
\text { easily understand the contents of the module }\end{array}$ \\
\hline
\end{tabular}

Some suggestions from the validator can help the researcher to revise the module such as: to improve the cover image so that it is more interesting and in accordance with the material discussed, the structure of the module is adjusted with the procedure of writing the module systematically delivered, the introduction explained how the use of module with operational word in accordance with the understanding of junior high school students, the delivery of indicators and learning objectives delivered in a more communicative language. In the contents section of the module, performed improvements to the presentation of modules with images and colours are more interesting so that it can cause student interest to read the module. The material is presented in full so that the module is the main reference in learning, to do the task and answer the questions on the assessment instrument. The cover section is revised by completing the glossary, so students can more easily understand the difficult words in the module. Overall learning activities in this module can help students understand the material presented independently.

Table 11:-Data Summary Assessment of Student Learning Outcomes

\begin{tabular}{|l|c|c|c|}
\hline & Trials & N-gain & category \\
\hline & cycle 1 & 0,18 & low \\
\hline & cycle 2 & 0,55 & medium \\
\hline & cycle 3 & 0,74 & high \\
\hline
\end{tabular}

Based on the data above, on the 1st cycle, Student learning outcomes based on the pre-test and post-test results are low, this shows no improvement in learning outcomes after using the module in learning, so it needs to be continued to cycle 2 . In cycle 1 , modules are incomplete and the language used is less communicative so students have 
difficulty learning by using modules. Student learning outcomes in cycle 2, including the medium category so that it needs to proceed to cycle 3 . In cycle 2 , the module instructions have been completed by using operational sentences and module structure is systematic, so students can read the module well and better understand the steps of active learning. The module dish is more interesting, but there are still some incomplete materials. After the module was revised and tested again, the result of learning cycle 3 shows the score of 0.74 that is a high category. This suggests that there is an increase in learning outcomes from before using the module and after using the module, meaning that the module developed is effective for science teaching in junior high. Data The results of learning in the form of repetitive results showed $92 \%$ of students achieve completeness, it supports data that learning outcomes have increased after using the module. This demonstrates scientific-based science modules on earth structure materials and their dynamics, effectively used in learning in junior high.

The student response data shows an average score of $88 \%$, it indicates that the student's response to the module is excellent, this data supports that the use of the module in junior high school is very effective in achieving the learning objectives.

\section{Conclusion:-}

The product validation results show valid criteria with score of 84.18 indicating that scientific-based IPA module on earth structure material and its dynamics is suitable for use in junior high school. Based on trial data, $\mathrm{N}$-gain score obtained is 0.74 indicates that there is an increase in learning outcomes after using the module as teaching materials. Assessment of learning outcomes shows $92 \%$ of students achieve minimal mastery and student responses show a very good response. This suggests that science-based IPA modules on Earth's material and dynamic materials are feasible and effective for use in junior high school learning.

\section{Referens:-}

1. Akbar, S (2013). Learning device instrument. Bandung: RemajaRosdakarya.

2. Anderson, L.W. \& D. Krathwohl, 2001. A Taxonomy for Learning, Teaching and Assessing. New York: Longman

3. Borg, W. \& Gall, M. 1983. Educational Research An Introduction. New York: Longman

4. Astuti, R.A., Nonoh S. A., Sukarmin (2016). Development of an Integrated Science Module Based on Four Pillars of Education with a Beach Theme to Improve Students' Scientific Attitudes.Jurnal Inkuiri Vol 5 (2).

5. Dahar, R.W (2006). Learning and learning theory. Jakarta: Erlangga.

6. Hake R. (1998). Interactive-Engagement versus Traditional Methods: A-SixThousand Student Survey of Mechanics Test Data for Introductory Physics Courses. American Journal of Physics, 66, Issue 1, pp. 64.

7. Mulyasa, E. (2003. Concept, Characteristics, Implementation, and Competency-based curriculum Innovation. Bandung: PT RemajaRosdakaryulyasa.

8. Pratiwi, H. E., Suwono, H., Handayani, N. (2013).Development of Hybrid Learning Based Biology Module to Improve Critical Thinking Ability and Learning Outcomes. Unnes Science EducationJournal Vol 2 (2).

9. Putra, S. (2013). Science-based Creative Teaching and Learning Design. Jogjakarta: DIVA Press.

10. Slavin, R. E. 2009. Educational Psychology; Theory and Practice $9^{\text {th }}$ Edition. New Jersey: Pearson.

11. Suciati da Suciati dan P. Irawan. (2014). Learning Theory and Motivation. Jakarta: PAU-PPAI Universitas Terbuka.

12. Sugiyanto, Ika K, Joko P. (2013). Development of Integrated Science-Based Module on Science-EnvironmentTechnology-Society (Salingtemas) with Biogas Themes. KauniaVol IX (1).

13. Sujiono. (2014). Development of Integrated Science Module Based on Problem Based Learning Motion Themes to Improve Students' Critical Thinking Ability. Not published.

14. Thiagarajan, et al.,(1974). Instructional Development for Training Teachers of Exceptional Children: A Sourcebook. Indiana: Indiana University.

15. Zubaidah, Sitiet al. (2015). Book of Natural Knowledge Science TeachersSMP/MTs. Jakarta: KementrianPendidikandanKebudayaan. 